\title{
Smart Management System using RFID to Control Traffic \& Vehical Parking
}

\author{
Vijayan T, Sridhar Raja D, Kalaiselvi B
}

\begin{abstract}
In India Traffic issues are multiplied each year because of increment in populace. This paper relies upon traffic and stopping the executives frameworks utilizing RFID innovation. RFID is put in vehicle and full database of vehicle and proprietor subtleties is put away. RFID peruser is set in all the traffic signals, Toll Gates and Parking regions, in view of the got information the traffic signal, toll expense and stopping space is overseen. In the event that any petty criminal offense like inappropriate protection, smoke test status or vehicle robbery is distinguished, the update sheet is made.
\end{abstract}

\section{Keywords: RFID, GSM and RFID Reader}

\section{INTRODUCTION}

In this quick, present day world we are confronting number of vehicle related issues. Here we attempted to take care of one such sort of issue utilizing new RFID innovation. We have taken traffic signal administration, vehicle smoke test, protection examination, toll the executives and leaving opening administration in this exploration.

One SEMI uninvolved RFID tag is put in vehicle put away with proprietor data, RC book, protection subtleties, administration subtleties and so on to send vehicle ID to traffic data database. [1],[3],[5]

. If vehicle security isn't restored in time, the action police will be frightened by blare sound or voice message.

The stopping space is overseen in the comparative manner. The vehicle tag is perused by leaving peruser and based that opening is declared and bill sum is created when the vehicle is going out. The toll is robotized by a similar chief utilizing RFID peruser. [2 ],[4],[6]

RFID: Radio recurrence distinguishing proof (RFID) has been around for a significant timeframe. Similarly starting late, then again, has the converging of lower cost and extended limits caused associations to research what RFID can achieve for them.

A vital push came while retailing beast Wal-Mart radically proclaimed that it would require its fundamental 100

Revised Manuscript Received on August 22, 2019.

Vijayan T Department of E\&I ,Bharath Institute of Higher Education \& Research,TamilNAdu Email: vijayan.eie@bharathuniv.ac.in

Sridhar raja D, Department of E\&I,Bharath Institute of Higher Education

\& Research,TamilNAdu Email: sridharraja.eie@bharathuniv.ac.in

Kalaiselvi, Department of E\&I,Bharath Institute of Higher Education \& Research,TamilNAdu Email: kalaiselvi.eie@bharathuniv.ac.in providers to supply RFID-engaged shipments by January 2005 espite the way that the essential concern story of that sending still can't seem to surface, it appears to reinforce the certain improvement of stock after and creation arrange organization toward RFID.

Addressing these inquiries will give an authoritative structure to RFID execution from both the specialized and business viewpoints.

\section{TECHNICAL OVERVIEW}

RFID names fall into two general classes, dynamic and reserved, dependent upon their wellspring of electrical power. Dynamic RFID marks contain their own specific power source, when in doubt an on-board battery. Inert names get control from the indication of an outside peruser. RFID perusers furthermore come in powerful and uninvolved varieties, dependent upon the kind of mark they read.

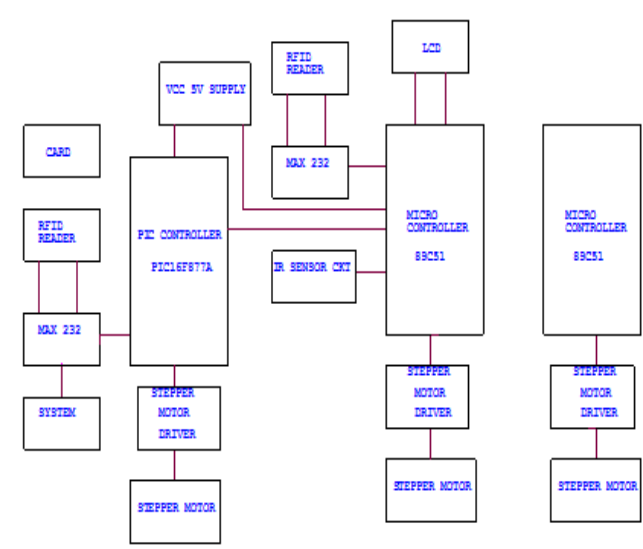

Fig.1,Block diagram

\section{A. Design:}

Here we have two areas of equipment. One is vehicle semi uninvolved RFID label segment and another is peruser and installed module put in rush hour gridlock signal, toll door and leaving region. [7],[9], [11] 


\section{B. Vehicle Section:}

In this segment semi uninvolved RFID tag is utilized. Semi inactive GAO 137005-9-P tag is utilized in our application. Its inclusion is $6 \mathrm{M}$ and 57 bytes of memory and $915 \mathrm{MHz}$ go. The vehicles Insurance, RC Book, Owner subtleties, Smoke test data's are put away in this tag. [8],[10],[12]

\section{Embedded Module:}

This is heart of the venture module. Here we have RFID peruser, microcontroller, computerized show, sound caution and vehicle speed estimating meter centered towards vehicles.

The RFID peruser is associated with sequential port of the microcontroller. It peruses Vehicles RFID label information and showcases it through presentation unit. The sound framework is utilized to declare the issues in the vehicle. The vehicle over speed pointer checks speed infringement. [13], [15],[17]

\section{IMPLEMENTATION}

The equipment is mostly focused on microcontroller implanted module advancement. Here we have utilized Atmel89c51 microcontroller and PIC16F877A microcontroller as a controlling gadget. In this inserted board RFID peruser, Display Unit, Stepper engines and Audio Unit (Speaker and intensifier) are interfaced with microcontroller.

At whatever point the vehicle go over the traffic signal the vehicle information is transmitted through RFID tag. On the off chance that guess vehicle isn't protected or not reestablished or inappropriate smoke test status that will be sent to the installed module through RFID peruser. At that point the presentation framework and sound framework educates the cop to do the activity. [14],[16], [18]

The police may record the charge sheet on the vehicle generally can be sent to the vehicle proprietor. To checkup the over speed the optical reflector sensor meter is utilized with RFID peruser by which we can at the same time check the over speed and other petty criminal offense issues. We can likewise deal with the blockage utilizing in this idea. In our customary rush hour gridlock control framework we are following time division the board idea.

That is empowering of sign a specific way depends on schedule. It doesn't consider the traffic thickness a specific way. At some point traffic might be high specifically bearing yet sign might be enacted some other way because of time inclination. [19],[21], [20],

Utilizing our framework we can give answer for this. Traffic is overseen astutely in this mode. The vehicle thickness a specific way is perused by RFID peruser and dependent on this the sign empowered. That is the sign need is chosen by traffic thickness. The more traffic region is given first need. By this we can likewise oversee traffic issue.

The stopping space the executives is done through programmed recognizable proof. At whatever point the vehicle is entered enter in to the leaving, the peruser gives vehicle data to the framework dependent on that opening is assigned and bill counter is begun. While takeoff the framework peruses the vehicle and creates the bill. Practically comparable way the toll entryway is mechanized.

\section{RFID Tag}

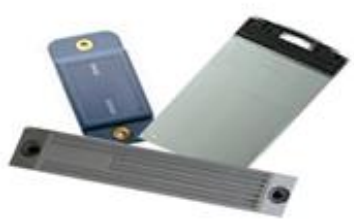

Fig 2:Rfid Tag
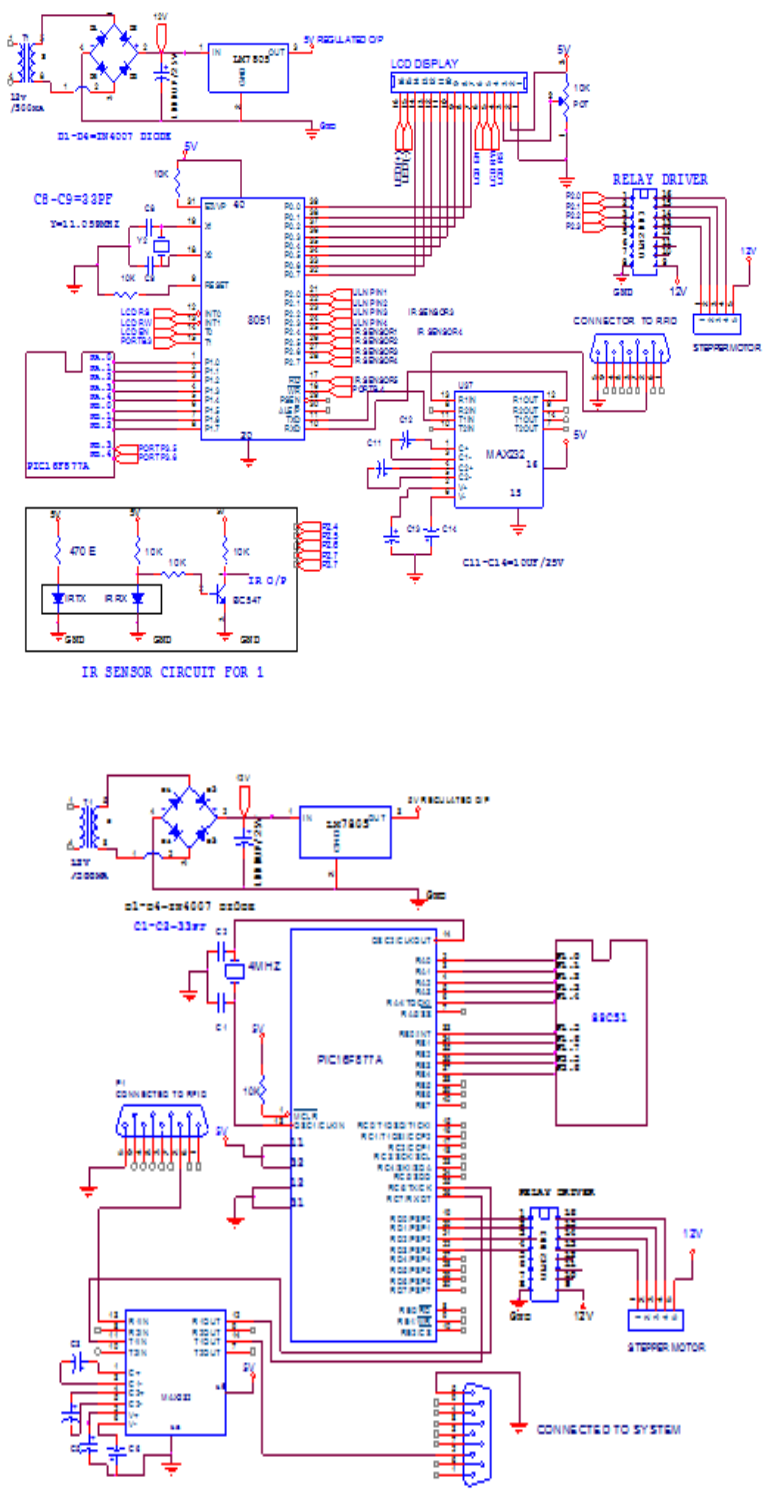

Fig3,4: schematic structure 


\section{CONCLUSION AND FUTURE WORK}

In this undertaking we planned traffic the executives, stopping opening administration and toll the board framework utilizing most recent RFID Technology. These days we are utilizing $\mathrm{N}$ no of vehicle the board frameworks however here we proposed an advanced arrangement utilizing RFID innovation. It reports practically all the petty criminal offense related issues. In created nations are widlely utilized RFID, GPS and GSM advancements for traffic the executives. Yet, in India we don't actualized any mechanized framework for vehicle the board because of financial status. Remembering this we have proposed this framework with ease. Our future work is to structure a mishap control with optical sensors and RFID sensors. We intended to control the increasing speed and break framework dependent on information's gotten from sensors.

\section{REFERENCES}

1. Sharma, R.K., Irusapparajan, G. \& Periyaazhagar, D. 2019, "Three-phase symmetric cascading Z-source seven levels multilevel inverter excited by multi carrier sinusoidal pulse width modulation scheme", International Journal of Innovative Technology and Exploring Engineering, vol. 8, no. 10, pp. 4269-4274.

2. Velavan, R., Bharanidharan, S. \& Sheeba, B. 2019, "EMF pollution Causes, effects and protection", International Journal of Innovative Technology and Exploring Engineering, vol. 8, no. 9 Special Issue 3, pp. 1166-1168.

3. Saravana, S., Balaji, S., Arulselvi, S. \& John Paul Praveen, A. 2019, "Reliable power quality monitoring and protection system", International Journal of Innovative Technology and Exploring Engineering, vol. 8, no. 9 Special Issue 3, pp. 644-645.

4. Tamil Selvan, S. \& Sundararajan, M. 2019, "Performance Parameters of 3 Value 8t Cntfet Based Sram Cell Design Using H-Spice", International Journal of Recent Technology and Engineering, vol. 8, no. 2 Special issue 5, pp. 22-27.

5. Jac Fredo, A.R., Abilash, R.S., Femi, R., Mythili, A. \& Kumar, C.S. 2019, "Classification of damages in composite images using Zernike moments and support vector machines", Composites Part B. Engineering, vol. 168, pp. 77-86.

6. Kathiravan, P. \& Govindaraju, C. 2019, "Design and evaluation of ultra gain isolated DC-DC converter for photovoltaic system", International Journal of Engineering and Advanced Technology, vol. 8, no. 5, pp. 2646-2651.

7. Kripa, N., Vasuki, R. \& Kishore Kanna, R. 2019, "Realtime neural interface controlled au-pair BIMA bot", International Journal of Recent Technology and Engineering, vol. 8, no. 1, pp. 992-994.

8. Mohanraj, Meenaa Kumari, M., Philomina, S. \& Jasmin, M. 2019, "In-situ humidity measurement of hydrogen fuel cell car using MEMS sensor", International Journal of Recent Technology and Engineering, vol. 8, no. 1, pp. 41-43.

9. Velmurugan, T. \& Prakash, S. 2019, "Artificial intelligent based distribution automation of swift fault detection isolation and power restoration for HT network", International Journal of Innovative Technology and Exploring Engineering, vol. 8, no. 6, pp. 1-6.

10. Dwarakesh, K. \& Prem Kumar, G. 2019, "Five-level inverter based sequential boost system using fuzzy logic controller", International Journal of Innovative Technology and Exploring Engineering, vol. 8, no. 6, pp. 12-19.

11. Anne Gifta, A. \& Hemavathi, G. 2019, "Analysis of grid tied solar PV system using ANFIS Algorithm", International Journal of Innovative Technology and Exploring Engineering, vol. 8, no. 6, pp. 312-316.

12. Jayavel, R., Rangaswamy, T.R. \& Prakash, S. 2019, "Efficient grid management system with renewable and conventional power sources", International Journal of Innovative Technology and Exploring Engineering, vol. 8, no. 6, pp. 287-289.

13. Hemavathi, G. \& Maheshwaran, S. 2019, "Proportional resonant controlled high gain step-up converter system with improved response", International Journal of Innovative Technology and Exploring Engineering, vol. 8, no. 6, pp. 317-323.

14. Periyaazhagar, D. \& Irusapparajan, G. 2019, "Design and completion of asymmetric single phase 27 level cascaded mli for various pwm scheme", International Journal of Innovative Technology and Exploring Engineering, vol. 8, no. 6, pp. 792-797.

15. Mahalakshmi, V. \& Vijayaragavan, S.P. 2019, "PV based power electronic converters for high voltage DC applications", International Journal of Recent Technology and Engineering, vol. 7, no. 6, pp 670-674.

16. Irusapparajan, G., Periyaazhagar, D., Prabaharan, N. \& Rini Ann Jerin, A. 2019, "Experimental verification of trinary DC source cascaded h-bridge multilevel inverter using unipolar pulse width modulation", Automatika, vol. 60, no. 1, pp. 19-27.

17. Sangeetha, G., Sherine, S., Arputharaju, K. \& Prakash, S. 2019, "On Line Monitoring of Higher Rated Alternator using Automated Generator Capability Curve Administer", Proceedings of the IEEE International Conference on \&amp;quot;Recent Trends in Electrical, Control and Communication\&amp;quot; RTECC 2018, pp. 176.

18. Bycil, V.J. \& Wiselin, M.C.J. 2019, "Modeling and analysis of vibration energy harvesting system using piezo stack", International Journal of Mechanical and Production Engineering Research and Development, vol. 9, no. Special Issue 1, pp. 523-533.

19. Sripada, A., Warrier, A., Kapoor, A., Gaur, H. \& Hemalatha, B. 2018 , "Dynamic lateral balance of humanoid robots on unstable surfaces", International Conference on Electrical, Electronics, Communication Computer Technologies and Optimization Techniques, ICEECCOT 2017, pp. 539.

20. Srinivasan, S., Thirumalaivasan, K. \& Sivakumaran, T.S. 2018 , "Performance evaluation of double-output luo converters", Journal of Advanced Research in Dynamical and Control Systems, vol. 10, no. 10 Special Issue, pp. 870-878.

21. Karthikayen, A. \& Selvakumar Raja, S. 2018, "A skellam distribution inspired trust factor-based selfish node detection technique in MANETs", Journal of Advanced Research in Dynamical and Control Systems, vol. 10, no. 13, pp. 940-949.

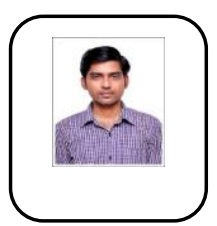

\section{AUTHORS PROFILE}

Vijayan T, Assistant Professor,Department of E\&I,Bharath Institute of Higher Education \& Research,TamilNAdu

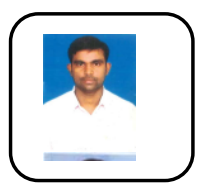

Sridhar raja D Assistant Professor,Department of E\&I ,Bharath Institute of Higher Education \& Research,TamilNAdu

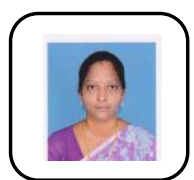

Kalaiselvi,, Assistant Professor,Department of E\&I ,Bharath Institute of Higher Education \& Research,TamilNAdu 